ACTA UNIVERSITATIS WRATISLAVIENSIS

No 3978

PRZEGLĄD PRAWA I ADMINISTRACJI CXX/1

WROCŁAW 2020

https://doi.org/10.19195/0137-1134.120.25

\author{
MACIEJ SZOSTAK \\ ORCID: 0000-0002-9880-0529 \\ Uniwersytet Wrocławski \\ Katedra Kryminologii i Nauk o Bezpieczeństwie

\section{KAMILA ZARYCHTA-ROMANOWSKA} \\ ORCID: 0000-0002-8403-0156 \\ Uniwersytet Wrocławski \\ Katedra Kryminologii i Nauk o Bezpieczeństwie
}

\title{
POLICYJNE STRATEGIE BEZPIECZEŃSTWA GRANIC UNII EUROPEJSKIEJ. POSTULATY DE LEGE LATA I DE LEGE FERENDA
}

\begin{abstract}
Abstrakt: Przedstawiając perspektywę współczesnych zagrożeń, autorzy analizują najnowsze koncepcje legislacyjne: bezpieczeństwa, kontroli policyjnej i zarządzania granicami Unii Europejskiej z perspektywy regulacji 2016/1624 i 2019/1896 o Europejskiej Straży Granicznej i Przybrzeżnej, Wspólnej Polityce Bezpieczeństwa i Obrony, Europejskiej Globalnej Strategii Bezpieczeństwa oraz Globalnym Pakcie Migracyjnym. Podejmując próbę holistycznej oceny wdrażanych koncepcji kontroli policyjnej i kryminologii granic (przede wszystkim przez pryzmat innowacyjności zintegrowanego zarządzania granicami i migracjami, zarówno w ujęciu europejskim, jak i globalnym), szczegółowo analizują oni uprawnienia Europejskiej Straży Granicznej, zwłaszcza w aspektach interoperacyjności, współpracy międzynarodowej oraz współpracy instytucjonalnej, wykazując niewykorzystanie potencjału nowej formacji, jaką jest „policja graniczna”. Niewystarczające legislacyjne ukonstytuowanie współpracy Straży z Biurem Europejskiego Prokuratora ogranicza bowiem skuteczność działań obu instytucji między innymi w zakresie zwalczania przestępstw terrorystycznych czy kontrolowania tak zwanych foreign fighterów. Autorzy postulują także umocowanie współpracy i synergii między agencjami wymiaru sprawiedliwości i Europejską Służbą Działań Zewnętrznych oraz wyposażenie formacji w niezbędne kompetencje wywiadowczo-operacyjne. Szczególną uwagę poświęcono konieczności wprowadzenia odpowiedniego (dostosowanego do zmieniających się potrzeb) treningu operacyjno-rozpoznawczego oraz szkoleń w zakresie międzynarodowego prawa humanitarnego i praw człowieka, tak by nowa „policja graniczna” podejmowała działania w sposób skuteczny i humanitarny. Prezentując proponowaną innowacyjność działań operacyjno-śledczych, wywiadu (między innymi profilowania cyfrowego), autorzy poddaja pod rozwage niewystarczające ukonstytuowanie kooperacji legislacyjnej ESGP z Prokuraturem UE. Autorzy akcentują konieczność pełnej współpracy państw UE w celu zwalczania przestępstw transgranicznych i terrorystycznych.
\end{abstract}


Słowa kluczowe: Frontex, Europejska Straż Graniczna i Przybrzeżna, polityka kontroli granic, policja granic, policyjna kontrola granic, ESGP, kryminologia graniczna, wywiad graniczny, europejskie bezpieczeństwo i obrona, Europejska Strategia Globalnego Bezpieczeństwa, globalne bezpieczeństwo, Globalny Pakt w sprawie Migracji ONZ, foreign fighters, przestępczość transgraniczna, terroryzm, Europejska Prokuratura, innowacyjne zarządzanie granicami, nowoczesny wywiad, interoperacyjność wymiaru sprawiedliwości EU, Europejska Służba Działań Zewnętrznych, EPPO, EEAS, zarządzanie kryzysowe, współpraca wymiaru policyjnego i sądowego, humanitarne zarządzanie granicami

Bezpieczeństwo i porządek publiczny stają się we współczesnej Europie „zagrożonym dobrem prawnym" wobec paradoksów kolejnych globalnych i regionalnych kryzysów, nieregularnych migracji, chaotycznych zmian strukturalnych w gospodarkach i społeczeństwach, wywoływanych globalizacją czy chociażby zmianami klimatycznymi. Coraz częściej występujące kryzysy ekonomiczne i gospodarcze, a przede wszystkim wielość, zmienność i dynamika konfliktów o charakterze militarnym, wymagają rewizji dotychczasowych aplikowanych i ukonstytuowanych przez wielolenie doświadczenia koncepcji ochrony i bezpieczeństwa granic Europy jako wspólnej przestrzeni geoplityczno-prawnej.

Odpowiedzią na kolejne, nowe wyzwania dla bezpieczeństwa obrony granic oraz prawdziwego ontologicznego braku poczucia bezpieczeństwa obywateli Unii Europejskiej jest utworzenie innowacyjnej, odpowiedniej, adekwatnej do czasu i potrzeb Europejskiej Straży Granicznej i Przybrzeżnej. Ewoluująca z Frontexu jako agencji administracyjno-strategicznego zarządzania (w zasadzie wyłącznie kwestiami zarządzania operacyjnego) zewnętrznymi granicami UE agencja jako formacja policyjna nabiera nowych kompetencji i uprawnień, dzięki którym będzie mogła sprostać wyzwaniom, jakie mogą z sobą przynieść kolejne globalne kryzysy.

Nasuwają się zatem pytania, czy te kompetencje nie są zbyt wąskie i czy mandat nowej służby uwzględnia konieczność implementacji inteligentnych technologii IT odpowiadających współczesnym zagrożeniom cybernetycznym?

Nowelizacja regulacji z 2016 roku odmieniła oblicze tej formacji. Agencja administracyjnego zarządzania granic stała się służbą o charakterze policyjnym ${ }^{1}$.

${ }^{1}$ Rozporządzenie Parlamentu Europejskiego i Rady (UE) 2016/1624 z dnia 14 września 2016 roku w sprawie Europejskiej Straży Granicznej i Przybrzeżnej oraz zmieniające rozporządzenie Parlamentu Europejskiego i Rady (UE) 2016/399 i uchylające rozporządzenie (WE) nr 863/2007 Parlamentu Europejskiego i Rady, rozporządzenie Rady (WE) nr 2007/2004 i decyzję Rady 2005/267/ WE, https://eur-lex.europa.eu/legal-content/PL/TXT/HTML/?uri=CELEX:32016R1624\&from=EN (dostęp: 1.02.2020). Szeroko na temat regulacji z 2016 roku, zwłaszcza w aspekcie centralno-europejskim, K. Zarychta-Romanowska, European border and coast guards agency - irregular migration management and creation and application of EU immigration law, ,Revista Facultatii de Drept Oradea" 2018, s. 258-270. 
Kolejnym etapem tej ewolucji jest przyjęta 13 listopada 2019 roku regulacja ${ }^{2}$, której celem jest stworzenie i dostosowanie kontroli policyjnej granic do aktualnych wyzwań oraz utworzenie formacji, która re aln i e będzie w stanie (współdziałając z odpowiednimi policjami granicznymi państw Europy) wdrożyć najnowszą politykę bezpieczeństwa granic.

Z pewnością są to bardzo ambitne założenia ustawodawcy. Stworzenie i wdrożenie na poziomie światowym, europejskim i krajowym kontroli policyjnej zarządzania granicami zewnętrznymi (będącego nieuniknioną konsekwencją swobody przepływu osób w obrębie Unii oraz podstawowym elementem przestrzeni wolności, bezpieczeństwa i sprawiedliwości) na pewno już jest koniecznością, a w przyszłości stanowić będzie jeszcze większe wyzwanie ${ }^{3}$.

Europejskie, zintegrowane zarządzanie granicami wydaje się, zdaniem legislatury europejskiej, absolutnie niezbędnym działaniem dla realnego i efektywnego zarządzania migracjami w Europie. Skuteczne zarządzanie przekraczaniem granic zewnętrznych oraz skuteczna i proporcjonalna odpowiedź na wyzwania związane z migracją, a także przeciwdziałanie potencjalnym przyszłym zagrożeniom i zwalczanie przestępczości transgranicznej ma doprowadzić do zapewnienia wysokiego poziomu bezpieczeństwa wewnętrznego i zewnętrznego Unii. Zapobieganie utraconemu ,poczuciu bezpieczeństwa” musi być funkcjonalnie powiązane z jednoczesną aplikacją acquis communataire, jeśli chodzi o swobodny przepływ osób wewnątrz UE zasadami humanitaryzmu poprzez pełne poszanowanie praw podstawnych oraz zobowiązań wynikających z umów prawnomiędzynarodowych ${ }^{4}$.

Rozwijając politykę globalnego bezpieczeństwa w ramach Europejskiej Strategii Globalnej ${ }^{5}$, legislatura Unii Europejskiej wyznacza nowe standardy polityki zagranicznej w aspekcie sensu largo rozumianego bezpieczeństwa, to znaczy politykę współdziałania i kooperacji oddziaływającą także w jak najszerszym zakresie na platformy komunikacji i kooperacji.

Globalne Strategie Bezpieczeństwa Publicznego wskazują na ewolucję europejskiej wizji rządu globalnego w XXI wieku. Jego fundament ma stanowić ochrona międzynarodowego ładu prawnego zgodnie z zasadami i umowami prawa międzynarodowego, korelująca z ugruntowanymi, upowszechnianymi i wzmocnionymi standardami praw człowieka.

2 Rozporządzenie Parlamentu Europejskiego i Rady (UE) 2019/1896 z dnia 13 listopada 2019 roku w sprawie Europejskiej Straży Granicznej i Przybrzeżnej oraz uchylenia rozporządzeń (UE) nr 1052/2013 i (UE) 2016/1624, https://eur-lex.europa.eu/legal-content/EN/TXT/?qid=158185 1570208\&uri=CELEX:32019R1896 (dostęp: 1.02.2020).

3 Pkt 1 preambuły rozporządzenia 2019/1896.

4 Cele rozporządzenia wymienione są w preambule do rozporządzenia 2019/1896.

5 https://eeas.europa.eu/headquarters/headquarters-homepage/17304/global-strategy-european-unions-foreign-and-security-policy_en (dostęp: 12.01.2020). 
Krystalizująca się „europejska” wizja globalnego bezpieczeństwa obejmuje swoim zakresem nie tylko terytorium Unii i nie ogranicza się wyłącznie do ochrony jej interesów. Jej celem jest zapewnienie globalnego bezpieczeństwa i pokoju, również w ramach Organizacji Narodów Zjednoczonych. Uwzględnione musi zostać wiele czynników zewnętrznych, a także nastąpić skoordynowanie reakcji na zagrożenia i uzgodnienie działań z innymi aktorami prawa międzynarodowego i tak zwanymi podmiotami niepaństwowymi ${ }^{6}$. Tym samym wskazywana jest konieczność wzmocnienia agencji zajmujących się pozyskiwaniem i wymianą informacji. Ta zewnętrzna proaktywność w kwestiach bezpieczeństwa widoczna jest zwłaszcza przez pryzmat globalnego zaangażowania Wspólnot Europejskich w prace nad dwoma globalnymi paktami - w sprawie migracji i uchodźctwa.

Budzący kontrowersje wśród państw członkowskich Światowy Pakt w sprawie Bezpiecznej, Uporządkowanej i Legalnej migracji (Global Compact for Safe, Orderly and Regular Migration) z 19 grudnia 2018 roku$^{7}$ został poparty przez 164 kraje ONZ, uzyskując akceptację polityczną Komisji Europejskiej już w trakcie prac nad jego projektem. W ramach Służby Działań Zewnętrznych Unia podejmowała wiele aktywności zmierzających do promocji idei uporządkowanej migracji, zwalczania migracji nieregularnych i zapobiegania wachlarzowi przestępstw związanych z nielegalnymi migracjami, zwłaszcza w krajach rozwijających się, będących najczęściej krajami pochodzenia migrantów nieregularnych.

Ten niewiążący dokument był „gorąco debatowany” na forum unijnym. Unia Europejska brała udział w pracach przygotowawczych, wyrażając w swoim stanowisku szereg postulatów, między innymi konieczność zagwarantowania wzmocnienia odpowiedniego, skutecznego zarządzania granicami zewnętrznymi i zapobiegania nielegalnym migracjom poprzez wzmocnienie krajowych i międzynarodowych środków walki z handlem ludźmi i w wieloaspektowym wymiarze z przemytem migrantów, zważywszy na „nagminne” powiązanie tego procederu z rozwijającymi się sieciami przestępczości zorganizowanej. Ta korelacja nielegalnej migracji oraz przestępczości zorganizowanej i transgranicznej jest bowiem czynnikiem zwiększającym częstotliwość i ułatwiającym nielegalne migracje. Przedstawiciele UE przy ONZ wskazywali, że pomimo suwerenności członków UE oraz praw i obowiązków państw w zakresie zarządzania i kontroli swoich granic konieczne jest pełne uzgodnienie ich z najwyższymi standardami i zobowiązaniami międzynarodowych praw człowieka, międzynarodowego prawa dotyczącego uchodźców, zasady non-refoulement oraz zakazem tak zwanego wydalenia zbiorowego.

Dialog bilateralny i regionalny wraz z pogłębioną współpracą z odpowiednimi partnerami (zwłaszcza policyjno-operacyjno-informacyjną), w szczególności

${ }^{6}$ EU Global Security Strategy, s. 9, https://eeas.europa.eu/topics/eu-global-strategy/17304/global-strategy-european-unions-foreign-and-security-policy_en (dostęp: 1.02.2020).

7 https://www.un.org/en/ga/search/view_doc.asp?symbol=A/RES/73/195 (dostęp: 1.02.2020). 
między krajami pochodzenia, tranzytu i przeznaczenia, był i pozostaje priorytetem unijnej dyplomacji ${ }^{8}$. Jest to znamienne, albowiem te same priorytety innowacyjnego, interoperacyjnego, interregionalego zarządzania granicami możemy znaleźć w najnowszej regulacji dotyczącej Europejskiej Straży Granicznej i Przybrzeżej, co wskazuje na kontynuowanie i rozwijanie wizji globalnej i bezpiecznej Europy.

Wizja ta zakłada zwiększenie możliwości reakcji, zwłaszcza na zewnętrzne kryzysy i destabilizujące region trudności naszych sąsiadów, także w aspektach bezpieczeństwa i obrony. Implikować to może konieczność rozwijania instrumentów kooperacji międzynarodowej lub transgranicznej, też w aspekcie polityki sąsiedztwa. Rozwijana solidarność wewnątrz Unii i udzielana sobie wzajemna pomoc ułatwi reakcje na wyzwania zewnętrzne i wewnętrzne ${ }^{9}$. Fundamentalne wyzwania dla bezpieczeństwa globalnego, takie jak: terroryzm, zagrożenia hybrydowe, bezpieczeństwo cybernetyczne i energetyczne, przestępczość zorganizowana czy zarządzanie granicami zewnętrznymi, wymagają bowiem fundamentalnej zmiany jakości kooperacji również organów i agencji Unii, zwłaszcza poprzez skuteczne pozyskiwanie i wymianę informacji, między innymi w ramach interoperacyjności wielkoskalowych systemów $\mathrm{IT}^{10}$.

Współpraca w ramach wspólnej polityki bezpieczeństwa i obrony (WPBiO), zakładająca bliską kooperację Europejskiej Straży Granicznej i Przybrzeżnej z wyspecjalizowanymi agencjami UE, ma zasadniczy cel strategiczny — poprawę ochrony granic, zwiększenie bezpieczeństwa morskiego i de facto stworzenie nowego modelu ,policingu” (ochrony granic) i bezpieczeństwa Unii i strefy Schengen ${ }^{11}$.

Ewolucja legislacji europejskiej w ciągu ostatnich dwóch lat wskazuje na wdrażanie idei bardzo silnej współpracy interinstytucjonalnej w celu realizacji nowej wizji ochrony granic, rozwijanej w nowej regulacji Europejskiej Straży Granicznej, zapewniającej interoperacyjność istniejących instrumentów i baz danych organów wymiaru sprawiedliwości, ale i powiązanie tych istotnych aspektów wymiaru sprawiedliwości z globalnym zakresem przestrzegania praw podstawowych i prawa międzynarodowego. Związane jest to z poszerzaniem kompetencji służb specjalnych, szczególnie unijnych agencji wywiadowczych, i koordynacją modelu

8 Szerzej na temat globalnego paktu migracyjnego zob. M. Szostak, B Wiśniewska-Paź, K. Zarychta, Krymigracja, kryminalizacja migracji a abolicja nieregularnej migracji, „Studia Sociologica” 11, 2019, nr 2; oraz eidem, Globalizacja nieregularnej migracji rozważania o wpływie międzynarodoweo kryzysu migracyjnego i jego implikacjach, „Transformacje” 2019, grudzień.

9 Szeroko na temat bezpieczeństwa granic jako priorytetu UE zob. K. Zarychta-Romanowska, European border..., s. 260 n. W kontekście najnowszej regulacji bardzo szeroko K. Zarychta-Romanowska, M. Szostak, Frontex 3.0 - rewolucyjny czy rewelacyjny - legislacyjno-policyjny paradygmat bezpieczeństwa granic Unii Europejskiej. Paneuropejska interpretacja i implementacja Intelligence-Led Policing, „Nowa Kodyfikacja Prawa Karnego” 50, 2018.

${ }^{10}$ EU Global Strategy, s. 17, https://eeas.europa.eu/topics/eu-global-strategy/17304/global-strategy-european-unions-foreign-and-security-policy_en (dostęp: 10.02.2020).

11 Ibidem. 
kooperacji instytucjonalnej.Wydaje się to kolejnym etapem tworzenia szerokiego zakresu instrumentów i mechanizmów operacyjnych, które w przyszłości umożliwią skuteczne działania wymiaru sprawiedliwości. Założenie bliskiej współpracy militarnej w ramach struktur NATO, powiązanie działań na rzecz ,globalnego pokoju" z ograniczeniem nielegalnej migracji, zauważenie militarnych aspektów konieczności zagwarantowania skutecznego mechanizmu ochrony granic łączy się bowiem z postulowanymi najwyższymi standardami przestrzegania prawa międzynarodowego oraz ochrony osób będących w różnych zakresie wrażliwymi na naruszenia ich sytuacji.

Poprzez liczne działania dyplomatyczne w związku z negocjowaniem Światowego Paktu Migracji i Światowego Paktu ds. Azylu uzgodniono wiele działań w celu nawiązania i rozwinięcia współpracy z krajami rozwijającymi się i będącymi w głównej mierze krajami pochodzenia bądź tranzytu migrantów zarówno regularnych, nieregularnych, jak i azylantów. Ambitne plany wyznaczone w 2016 roku w Europejskiej Strategii Globalnego Bezpieczeństwa, wdrażane stopniowo przez UE, nabyły nowego wymiaru w 2019 roku, w którym jeszcze mocniej podkreślono istotne, już realizowane działania. Są to między innymi: wsparcie informacyjno-wywiadowcze dla organów i członków Unii, odnoszące się do wdrażanych, wspólnych działań w zakresie intensyfikacji wymiany danych pomiędzy państwami i organami Unii, kreacja koherentnej strategii zakładającej wspólne działania i pomoc w ramach realizacji globalnie bezpiecznej i solidarnej Europy ${ }^{12}$.

W tym zakresie konieczne jest zapewnienie interoperacyjności Unii w aspekcie wewnętrznym - pomiędzy jej centralnymi organami i agencjami zdecentralizowanymi — oraz $\mathrm{w}$ aspekcie zewnętrznym $-\mathrm{z}$ organizacjami międzynarodowymi, takimi jak NATO i ONZ (wraz z działającymi pod jej auspicjami: Światową Organizacją do Spraw Migracji, Biurami Wysokich Komisarzy ds. Uchodźców i ds. Praw Człowieka, Biurem ds. Zwalczania Przestępczosci i narkotyków oraz Interpolu), między innymi poprzez zwiększenie mandatu PESCO. Od dłuższego czasu „snuta wizja” rozbudowy, wzmocnienia i „operacjonalizacji synergii” cywilno-wojskowej powinna w większym zakresie zasadzać się na rozwijaniu istniejących i planowanych rozwiązań w ramach Europejskiej Straży Granicznej i Przybrzeżej, o potencjale wzmocnienia współpracy obronnej w ramach potencjału militarnego państw Unii. Skoro bowiem Unia Europejska ma możliwość zachowania i rozwoju jednolitego zestawu sił państw członkowskich za pośrednictwem PESCO, mogłaby dążyć do przewartościowania swojej specyfikacji informacjno-operacyjnej i interoperacyjności militarnej. Tworzona europejska baza obronna i technologiczna przemysłowa, połączona z rozwojem własnych technologii militarnych i cyberbepieczeństwa, ugruntuje pozycję Unii na arenie międzynarodowej, co prawdopodobnie rozwinie jej potencjał wywiadowczy, technologiczny i gospodarczy. Działania te nie tylko umożliwią stworzenie i rozwój

12 https://eeas.europa.eu/sites/eeas/files/eu_global_strategy_2019 (dostęp: 10.02.2020). 
konkurencyjnych technologii militarnych, wywiadowczych i cybernetycznych, ale też mogą wpłynąć na wzmocnienie operacyjnej gotowości służb policyjnych, w tym Europejskiej Straży Granicznej i Przybrzeżnej.

Ten zwrot w kreowaniu polityki ochrony granic $\mathrm{w}$ ramach globalnej strategii bezpieczeństwa na bardziej proaktywną niestety jest w niewystarczająco odpowiedni sposób przedstawiony i ugruntowany w przyjętym przez Parlament Europejski projekcie, określanym jako Frotnex 3.0 lub EBCG 2.0. W art. 29 rozporządzenia 2019/1896 13 określono część kompetencji wywiadowczych nowej Europejskiej Straży Granicznej i Przybrzeżnej w ramach analizy ryzyka. Dane na temat sytuacji, tendencji i potencjalnych zagrożeń na granicach zewnętrznych oraz w dziedzinie powrotów, przekazywane regularnie lub na wniosek EBCG, stosownie do art. 29 pkt 5 przez państwa członkowskie, mają zawierać takie informacje, jak: dane statystyczne oraz operacyjne zbierane $\mathrm{w}$ związku $\mathrm{z}$ europejskim zintegrowanym zarządzaniem granicami, które są zawarte w wykazie obowiązkowych informacji i danych, które mają być wymieniane $\mathrm{z}$ agencją, zgodnie $\mathrm{z}$ art. 100 ust. 2 lit. e), a także informacje pozyskane $z$ analitycznej bazy krajowego obrazu sytuacji, zgodnie z art. 25. Podkreślając istotę kooperacji z Eurosurem w celu dostarczenia strukturom krajowym i unijnym oraz samej agencji koniecznych do prawidłowego działania regularnych, rzetelnych i ekonomicznie uzasadnionych danych o sytuacji na granicach zewnętrznych i sąsiadującego z nimi tak zwanego pogranicza Unii, ograniczono jednocześnie potencjał rozwoju nowej formacji, nie przydając jej instrumentów, które pozwoliłyby odkryć potencjał tej formacji, a jednocześnie wzmocnić potencjał Unii w kontekście przestrzeni wolności, bezpieczeństwa i sprawiedliwości poprzez silny mandat do wdrażnia strategii antyterrorystycznej.

Co prawda w pkt 40 preambuły możemy zauważyć odniesienia do analiz ryzyka, które winny przyczynić się do zapobiegania przestępczości transgranicznej, w tym ułatwiania niedozwolonego przekraczania granicy, handlu ludźmi, terroryzmu oraz zagrożeń typu hybrydowego. Analizy ryzyka powinny jednak odnosić się też do sytuacji w odpowiednich państwach trzecich, tak aby umożliwić wprowadzenie skutecznych środków lub sprostać wykrytym zagrożeniom i ryzykom $\mathrm{w}$ celu usprawnienia zintegrowanego zarządzania granicami zewnętrznymi. Postulowany obraz został uzupełniony przez pkt 41 preambuły w zakresie celów, jakimi są: przeciwdziałanie i wykrywanie przestępczości transgranicznej, takiej jak przemyt migrantów, handel ludźmi oraz terroryzm, oraz ostatecznie postulowana kompetencja do reagowania na ujawnione przypadkui przestępczości między innymi w sytuacjach, gdy ESGP uzyska stosowne informacje dzięki prowadzonym przez siebie operacjom (powinna przy tym koordynować swoje działania z Europolem jako agencją odpowiedzialną za wspieranie i zwiększanie skuteczności działań

$13 \mathrm{https} / /$ eur-lex.europa.eu/legal-content/PL/TXT/HTML/?uri=CELEX:32019R1896 \&qid=1581851570208\&from=PL\#d1e39-1-1 (dostęp: 10.02.2020). 
państw członkowskich oraz ich współpracy w zakresie zapobiegania i zwalczania przestępczości działajacej na terenie co najmniej dwóch państw członkowskich).

Skoro „wymiar transgraniczny” odnosi się do powiązania czynów zabronionych bezpośrednio z niedozwolonym przekraczaniem granic zewnętrznych UE (w tym w ramach handlu ludźmi lub przemytu migrantów), powinien również zawierać aspekt szczegółowy, na przykład zwalczanie zjawiska foreign fighters ${ }^{14}$ i terroryzmu, zwłaszcza że wkrótce działanie ma rozpocząć Biuro Europejskiego Prokuratora Publicznego, mającego mieć uprawnienia proaktywnego działania śledczego, nie tylko co do prowadzenia dochodzeń w zaresie wykrywania i ścigania przestępstw przeciwko budżetowi UE i oszustw w zakresie podatku VAT, lecz przede wszystkim w ramach swoich nowych kompetencji, czyli zwalczania transgranicznych przestępstw terrorystycznych. Niestety jeszcze nie nastąpiła finalizacja prac nad rozszerzeniem kompetencji śledczych Prokuratury Europejskiej, a zatem jeszcze nie zostały przyjęte ,zapisy ponaglające" ustrukturyzowanie władz krajowych, aby gromadziły więcej informacji w proaktywny i ukierunkowany sposób, realizując obowiązek organów krajowych dzielenia się informacjami z Eurojustem i Europolem, czy też postulowany w projekcie nowy model przetwarzania, operowania i gromadzenia danych szczególnie chronionych i poufnych informacji przez Prokuraturę Europejską i jej krajowe delegatury.

Wydaje się jednak, że nie wzięto pod uwagę nieodzownej współpracy na styku Europejska Prokuratura-Europol-Eurojust z nową formacją policyjną, jaką jest Europejska Straż Graniczna i Przybrzeżna, w zakresie zwalczania przestępstw terrorystycznych o charakterze transgranicznym, pomijając tym samym ważny aspekt i niewątpliwie część zakresu działania „europejskich pograniczników”. Nie wzięto również pod uwagę niewątpliwej użyteczności straży w zwalczaniu przestępczości ekonomicznej, wpisującej się w unijny mandat prokuratorski. Sformalizowanie bowiem współpracy w tym zakresie i włączenie Europejskiej Straży Granicznej i Przybrzeżnej do współpracy z Europejską Prokuraturą byłoby bardzo utylitarnym, istotnym „krokiem milowym” do synergii wymiaru sprawiedliwości w Europie.

Widoczne i potencjalne bariery współpracy pomiędzy instytucjami europejskimi odpowiedzianymi za poziom bezpieczeństwa, a także luki prawne, dysonanse w różnych obszarach funkcjowania Wspólnoty (zauważalne przez opinię publiczną), konkurujące z sobą akwności wewnątrz instytucji europejskich są z sobą powiązane, a występująca pomiędzy nimi rywalizacja i ujawnianie publiczne wskazanych trudności i partykularnych animozji mogą ,zachwiać w posadach” fundamenty unijnych swobód obywatelskich, które stanowią przecież esencję idei Zjednoczonej Wspólnoty Europejskiej.

Docierające do opinii publicznej informacje o przypadkach naruszeń granic zewnętrznych, jak i wewnętrznych UE stanowią poważne zagrożenie dalszego

14 Więcej na ten temat K. Zarychta-Romanowska, Foreign fighters as a threat to Polish security and sovereignty, „Revista Facultății de Drept Oradea” 2019, s. 95-122. 
istnienia strefy Schengen. Dotychczasowe nieefektywne reakcje służb unijnych na zagrożenia i kryzysy migracyjne ostatnich lat powodują coraz silniej odczuwalny społeczny brak poczucia bezpieczeństwa obywateli UE, tym samym dających przyzwolenie na proces ograniczania ich własnego, pełnego korzystania z podstawowych praw i wolności Europejczyków, w rezultacie prowadząc do głębokiego kryzysu instytucjalnego i politycznego. Jego przejawem jest utrata zaufania do rządów i organów unijnych odpowiedzialnych za utrzymywanie bezpieczeństwa i porządku publicznego, a tym samym idei europejskich, czego skutkiem jest chociażby wzrost popularności ruchów narodowo-ksenofobiczno-populistycznych. Wzmocniona współpraca, zwłaszcza w zakresie kooperacji europejskich instytucji wymiaru sprawiedliwości, migracji i spraw wewnętrznych, w rezultacie może zapewnić renesans społeczeństwa UE i idei podstawowych wolności, przy jednoczesnym stworzeniu korzystnego klimatu gospodarczego.

Europejska Straż Graniczna i Przybrzeżna ma, oprócz klasycznych działań operacyjno-śledczych, takich jak na przykład monitoring strategicznych rejonów granicznych, jak porty czy tereny nadbrzeżne państw trzecich, prowadzić działania selektywnego monitorowania wyznaczonych portów i terenów nadbrzeżnych państw trzecich, wskazanych przez służbę wywiadu. Na podstawie analizy ryzyka i informacji sprawdzane są punkty „przyjmowania na pokład” albo ,punkty tranzytowe" dla pojazdów lub statków morskich i innych jednostek wykorzystywanych do celów związanych z nielegalną imigracją lub przestępczością transgraniczną. W preambule aktu, między innymi w pkt 15, wskazano na wagę zintegrowanego zarządzania granicami na poziomie europejskim dla funkcjonowania formacji. Jego wdrożenie ma być uzupełniane przez zintegrowanie planowania między państwami członkowskimi a nową agencją. Powinno to mieć miejsce przede wszystkim w zakresie działań odnoszących się do kreacji odpowiedniego systemu kontroli i wdrożenia mechanizmów umożliwiających szybką reakcję na pojawiające się wyzwania i kryzysy. Sformułowanie i wdrożenie mechanizmu planowania ewentualnościowego oraz koordynacji długoterminowego rozwoju zdolności operacyjnej Straży Granicznej i Przybrzeżnej, zwłaszcza w ramach jej potencjału ludzkiego i technologicznego, jest kolejnym, niezbędnym krokiem jej dalszego rozwoju. Nowa formacja policji granicznej Unii powinna zatem zostać stworzona spośród najlepiej wykwalifikowanych funkcjonariuszy, uzbrojonych w najbardziej nowoczesne instrumenty pracy operacyjnej, szczególnie w zakresie strategii i taktyki operacyjno-informacyjno-wywiadowczej.

Najważniejszym zadaniem do realizacji wydaje się zapewnienie „skrojonego na miarę" systemu szkolnictwa i aktywności treningowych, który nie tylko będzie wykorzystywany w trakcie rekrutacji do nowej formacji, ale przede wszystkim pomoże w rozwijaniu i podnoszeniu zdolności operacyjnej, umiejętności technologicznych i taktycznych przyszłych funkcjonariuszy nowej Europejskiej Straży Granicznej i Przybrzeżnej, rekrutowanych z innych służb. Przygotowanie „europejskich pograniczników” na wyzwania, jakie niesie z sobą odpowiednie 
wdrażanie zasad profilaktyki i prewencji kryminalnej, wiedzy kryminologiczno-wiktymologicznej i wsparcia psychologicznego, zachowując w jak najszerszym zakresie najwyższe standardy ochrony praw podstawowych, powinno być nadrzędnym celem ESGP na najbliższe lata, ponieważ tym samym pozwoli na skuteczniejsze zwalczanie przestępczości transgranicznej i pozyskiwanie szerszego spektrum relewantnych prawnie informacji.

Wydaje się zatem, iż z roku na rok szkoleniowy potencjał Europejskiej Straży Granicznej i Przybrzeża będzie się rozwijał „geometrycznie”. Służba ta może stać się pionierem i nowym liderem naukowo-szkoleniowym „praktyki kryminologicznej”, łącząc ją z celami, jakimi są między innymi zadania polegające na określeniu standardów technicznych wymiany informacji (zob. pkt 14a preambuły, rozwijany dalej w tekście) oraz standardów nadzoru granic zewnętrznych. Wyłącznie doradcza rola oraz określanie minimalnych standardów aktywności wydaje się zbyt mocno ograniczoną kompetencją tej agencji. Jedną z zasadniczych ról agencji powinno być ustanowienie strategii operacyjnej i technicznej (w ramach wieloletniego cyklu polityki strategicznej na rzecz wdrożenia zintegrowanego zarządania granicami zewnętrznymi), dzięki czemu możliwe stanie się sprawne przeprowadzanie wspólnych operacji i szybkich interwencji na granicach. W tym celu nieodzowne jest stworzenie innowacyjnej, efektywnej i intuicyjnej wręcz strategii działania wywiadowczo-operacyjnego służby, która w ramach koherentnej wizji nadzorowania granic będzie w stanie nie tylko wypełniać funkcje stricte ich ochrony, ale faktycznie realizować wizję globalnego bezpieczeństwa w sposób proaktywny. Takie praktyczne wdrożenia środków (w sytuacji wymagającej pilnego podjęcia działań na granicach zewnętrznych, udzielania pomocy technicznej i operacyjnej w celu wsparcia, organizowania, koordynowania i prowadzania operacji i działań operacyjnych oraz właściwego organizowania operacji powrotowych) wzmocni pozycję służby i przyczyni się do wzrostu jej potencjału międzynarodowego, również $\mathrm{w}$ aspekcie wywiadowczym.

Zważywszy na konieczne współdziałanie tej agencji z Europejską Służbą Działań Zewnętrznych, można zauważyć, iż legislator europejski w zbyt małym stopniu uwzględnił potencjał do realizacji polityki obronnej i polityki zagranicznej, jaki może mieć nowa agencja. Naturalnie konieczne jest skuteczne i pełne wdrożenie kodeksu granicznego Schengen, niemniej jednak można się zastanowić, czy zostawienie szerokiej uznawalności państwom członkowskim w znaczącym stopniu nie ograniczy potencjału obronnego i funkcjonowania zintegrowanego zarządzania granicami zewnętrznymi. Należy wziąć pod uwagę, że jednym z uprawnień nowej straży będzie również podejmowanie działań zmierzających do kontroli, rozpoznawania, wykrywania, identyfikowania statków morskich, powietrznych i innych jednostek na pełnym morzu w sytuacji potencjalnego wykorzystania ich do aktywności związanych z nielegalną imigracją lub przestępczością transgraniczną. Tym samym możliwe będzie monitorowanie wyznaczonych stref na obszarach morskich, stref powietrznych w celu: wykrywania, identyfiko- 
wania i śledzenia „wachlarza jednostek”, wykorzystywanych (lub co do których zachodzi podejrzenie, że są wykorzystywane) do celów związanych z nielegalną imigracją lub przestępczością transgraniczną.

Zważywszy na nexus: nielegalna migracja — przestępczość transgraniczna - fenomen foreign fighters (zradykalizowanych bojowników biorących udział w działaniach wojennych poza granicami kraju pochodzenia), powracających do Europy lub też przygotowujących się poza jej granicami do podejmowania działań o charakterze terrorystycznym, zastanawia fakt pominięcia możliwości współpracy EBCG z Prokuraturą Europejską. Uznając w pkt 114 preambuły ${ }^{15}$, iż Prokuratura Europejska powinna mieć możliwość prowadzenia postępowań przygotowawczych oraz wnoszenia i popierania oskarżeń w sprawie nadużyć finansowych i innych przestępstw naruszających interesy finansowe Unii, nie odniesiono się w żaden sposób do najnowszej, postulowanej kompetencji Prokuratury Europejskiej, to jest do prowadzenia postępowań transgranicznych w sprawach związanych z terroryzmem, ani też nie wzmocniono synergii pomiędzy agencjami wymiaru sprawiedliwości w sprawach terrorystycznych w sposób bardziej rozwinięty i kompulsoryjny ${ }^{16}$. Działania wywiadowcze ESGP powinny również obejmować analizę oddziaływania na środowisko w odniesieniu do wyznaczonych stref na obszarach morskich oraz na lądowej i powietrznej granicy zewnętrznej, prowadzonej w celu zoptymalizowania działań w zakresie monitorowania i patrolowania. Taki selektywny monitoring wyznaczonych stref przedgranicznych przy granicach zewnętrznych, które zostały wskazane na podstawie analizy ryzyka i informacji jako potencjalne strefy wyjazdu lub tranzytu do celów nielegalnej imigracji lub przestępczości transgranicznej, jest bardzo rozsądnym ekonomicznie rozwiązaniem, natomiast powinno być ono rozszerzone przez wywiad technologiczny, zwłaszcza „w absolutnym minimum”, przez szerokie wykorzystanie dronów i monitoringu działania danych zbieranych przez anteny sieci komórkowych BTS ${ }^{17}$.

Wskazywane zadanie monitorowania i analizowania tendencji, liczebności i tras przepływów migracyjnych do Unii i wewnątrz Unii oraz monitorowania mediów, wywiadu ze źródeł jawnych i analizy działalności w Internecie (zgodnie z dyrektywą Parlamentu Europejskiego i Rady (UE) 2016/680 lub z rozporządzeniem (UE) 2016/679), stosownie do przypadku, w celu zapobiegania nielegalnej imigracji lub przestępczości transgranicznej został bardzo zasadnie rozwinięty

15 Zgodnie z rozporządzeniem Rady (UE) 2017/1939 i zgodnie z dyrektywą Parlamentu Europejskiego i Rady (UE) 2017/1371.

$16 \mathrm{https}$ :/ec.europa.eu/commission/sites/beta-political/files/soteu2018-extend-public-prosecutors-office-communication-641_en.pdf (dostęp: 10.02.2020).

17 Ciekawie w tym kontekście M. Szostak, Pomiędzy humanistyka a inteligentnymi technologiami przyszłości: metodologiczne korelacje badawcze na przykładzie tzw. kontrowersyjnych ruchów religijnych, [w:] Problemy współczesnego prawa karnego i polityki kryminalnej: księga jubileuszowa Profesor Zofii Sienkiewicz, red. M. Bojarski, J. Brzezińska, K. Łucarz, Wrocław 2015, s. $473-482$. 
o szeroki zakres analizy informacji pochodzących z wielkoskalowych systemów informatycznych w celu wykrywania zmieniających się szlaków i metod wykorzystywanych do celów nielegalnej imigracji i przestępczości transgranicznej. Brakuje jednak zagwarantowania nowej służbie możliwości formalnego wnioskowania o udostępnienie posiadanych danych wrażliwych (zwłaszcza zawartych w sieciach społecznościowych i komunikatorach) odnoszących się do ekstremalnych sytuacji multiskalowego zagrożenia bezpieczeństwa publicznego, szczególnie o inklinacjach terrorystycznych.

Reasumując, należy stwierdzić, że pomimo wskazanych problemów, z którymi w najbliższej przyszłości będzie musiała zmierzyć się nowa Europejska Straż Graniczna i Przybrzeżna, jej utworzenie, aktywność oraz potencjał sprawczy to ogromny „krok do przodu we właściwym kierunku” w perspektywie ochrony porządku i bezpieczeństwa Unii Europejskiej, być może najważniejszy z punktu widzenia ochrony mieszkańców UE i możliwości realizacji idei wspólnej Europy w przyszłości oraz globalnego bezpieczeństwa międzynarodowego.

\section{BORDER POLICING AND STRATEGIES OF THE EU'S BORDER SECURITY - DE LEGE LATA AND DE LEGE FERENDA POSTULATES}

\section{Summary}

While presenting the landscape of contemporary insecurities, the authors investigate the latest legislative concepts of the European Union's concepts of security, policing and border management from the lenses of Regulations 2016/1624 and 2019/1896 on the European Border and Coast Guard, Common Security and Defence Policy, European Global Security Strategy and the UN Global Compact on Migration.

In an attempt to holistically assess the implemented concepts of police control and border criminology, above all through the prism of the innovation of integrated border and migration management, both in European and global terms, they analyse in detail the powers of the European Border and Coast Guard Agency, especially with regard to their interoperability, international and interinstitutional cooperation.

They point out as well the untapped potential of the formation of a new border police force. The insufficiently constituted cooperation of the Border Guard Agency with the Office of the European public Prosecutor limits the effectiveness of the activities of both institutions, i.e. to combat terrorist offences, trans-border trafficking of people and goods, or even to control so-called foreign fighters.

Strengthening cooperation and synergies between judicial and law enforcement agencies and the European External Action Service, providing the formation with the necessary intelligence and military competence is suggested by the authors.

Particular attention was devoted to the need for appropriate needs, adaptable to change - formation and investigative-military training, as well as education on international humanitarian law and human rights, so that the border police may carry out their duties in an effective yet humanitarian manner. 
Describing the proposed innovation in policing, not limited to operational and investigative activities, but rightly covering modern intelligence and digital/cyber profiling, among others, the authors consider a formally established close cooperation between EU Border Guards and the EU Public Prosecutor alongside the formalisation of the obligation to provide sincere and full cooperation from other EU countries to combat cross-border and terrorist related offences as a very much needed and desired axiomatic milestone in EU legislation. The authors provide a number of suggestions that may contribute to humanitarian, effective, and innovative border and migration management, and the fight against transnational organised crime and irregular migration phenomena.

Keywords: Frontex, European border and coast guard agency, EBCG, border policing, border criminology, border intelligence, European security, global security, EU global security strategies, UN Global Compact on Migration, foreign fighters, cross-border crime, transnational terrorism, European Public Prosecutor Office, EPPO, EEAS, crisis management, innovative border management, interoperability, EU Law enforcement cooperation, innovative border intelligence, innovative border training and education, humanitarian border management

\section{BIBLIOGRAFIA}

Szostak M., Pomiędzy humanistyka a inteligentnymi technologiami przyszłości: metodologiczne korelacje badawcze na przykładzie tzw. kontrowersyjnych ruchów religijnych, [w:] Problemy współczesnego prawa karnego i polityki kryminalnej: księga jubileuszowa Profesor Zofii Sienkiewicz, red. M. Bojarski, J. Brzezińska, K. Łucarz, Wrocław 2015.

Szostak M., Wiśniewska-Paź B., Zarychta K., Globalizacja nieregularnej migracji - rozważania o wpływie międzynarodowego kryzysu migracyjnego i jego implikacjach, „Transformacje” 2019, grudzień.

Szostak M., Wiśniewska-Paź B., Zarychta K., Krymigracja, kryminalizacja migracji a abolicja nieregularnej migracji, „Studia Sociologica” 11, 2019, nr 2.

Zarychta-Romanowska K., European border and coast guards agency - irregular migration management and creation and application of EU immigration law, „Revista Facultatii de Drept Oradea” 2018.

Zarychta-Romanowska K., Foreign fighters as a threat to Polish security and sovereignty, „Revista Facultăţii de Drept Oradea” 2019.

Zarychta-Romanowska K., Szostak M., Frontex 3.0 - rewolucyjny czy rewelacyjny - legislacyjno-policyjny paradygmat bezpieczeństwa granic Unii Europejskiej. Paneuropejska interpretacja i implementacja Intelligence-Led Policing, „Nowa Kodyfikacja Prawa Karnego” 50, 2018. 